Наташа Р. Куртума ${ }^{1}$, докторанд,

Филозофски факултет, Универзитет у Новом Саду Доц. др Гордана М. Ристић Филозофски факултет, Универзитет у Новом Саду
UDK 373.3:: 81'243: 81'373.7

Оригинални наични рад Примљен: 24. 11. 2017. Прихваћен: 20. 1. 2018. BIBLID 0553-4569, 63 (2017), 1, p. 52-63. doi: $10.19090 /$ ps.2017.1.52-63

\title{
О ВАЖНОСТИ ИМПЛЕМЕНТАЦИЈЕ ФРАЗЕОЛОГИЗАМА У НАСТАВИ СТРАНОГ ЈЕЗИКА
}

\author{
Anстракт
}

Циљеви савремене наставе страног језика су, према Заједничком европском референтном оквиру за језике, усмерени на комуникацију односно развијане опитих, а пре свега комуникативних компетениија. Све чешће се намеће неопходност познавања страног језика до те мере да можемо без великих проблема да комуницирамо са говорницима одређеног језика, а да при том владағе страним језиком није сведено на познавање само одређених области језика. За успешну, свакодневну комуникацију је, између осталог, битно познаване фразеолошких јединица неког језика. У овом раду се поставља питање да ли су и у којој мери наставници страног језика свесни важности имплементаџије фразеологизама у наставу страног језика. Техника којом смо се служили приликом испитивања је анкетирање, при чему инструменте анализе чини анкетни лист са петостепеном Ликертовом скалом. За поменуту анализу употребљена је дескриптивна статистика као вид квантитативне анализе података након које следи дескрипичја резултата. Циљ нашег истраживања је, уз помоћ дескриптивне статистике, извођене општих закључака у вези са ставовима наставника на одређене исказе и утврђивање тачности наших претпоставки док се фокусирамо на важност имплементације фразеолошких јединица у настави страног језика. За даља истраживања интересантно би било анализирати корелаичју добијених одговора између основног односно средњег образовања, година стажа наставника и страног језика који се предаје. Сматрамо да би овај рад могао бити полазиште за даљу анализу у оквиру теме.

Кључне речи: комуникативна компетенција, фразеолошка компетенција, фразеологизми, настава страног језика, ставови наставника

\footnotetext{
${ }^{1}$ natasakurtuma@hotmail.com
} 


\section{Увод}

Налазимо се у времену у којем је познавање бар једног страног језика од великог значаја, како бисмо могли без потешкоћа да функционишемо, како у пословном тако и у приватном животу. Није довољно познавање само одређених области језика како би се задовољила све чешће наметнута потреба познавања страног језика до те мере да можемо без већих проблема да комуницирамо са говорницима неког језика. Под језичком компетенцијом већина подразумева познавање граматичких правила и одређеног броја речи страног језика, мислећи при том на одређени оптимум речи, али не и на познавање фразеолошких јединица. Међутим, да бисмо овладали страним језиком и били у стању да комуницирамо са говорницима неког језика, неопходно је да познајемо, између осталог, и фразеологију тог језика. Највећи проблем је то што значај фразеологизама у језику често није довољно експлицитно наглашен, када је учење страног језика у питању. Неретко је случај да су фразеологизми потцењени у настави и нису у довољној мери етикетирани као важна компонента комуникативне компетенције. Овим и сличним проблемима су се између осталог бавили: Ханс Бикис и Уте Паули, Клаус Ерхард, Волфганг Флајшер и Алисон Bpej (Bickes и Pauli, 2009; Ehrhardt, 2014; Fleischer, 1997; Wray, 2007). У овом раду се поставља питање да ли су и у којој мери наставници страног језика свесни важности имплементације фразеолошких јединица у наставу страног језика. Под називом наставник страног језика подразумевамо предаваче страног језика како у основним и средњим школама тако и у школама страних језика. Циљ нам је, између осталог, да уз помоћ анкетирања и процењивања, користећи притом дескриптивну статистику, дамо одговоре на ово питање. У те сврхе смо анализирали скале процене које су попуњавали наставници страног језика, а у вези са важношћу интегрисања фразеологизама у наставу страног језика.

\section{О фразеологизмима}

\section{Дефиниција фразеологизама}

Консултујући домаћу и страну литературу закључујемо да је готово немогуће дати јединствену дефиницију фразеологизама, али је према многим ауторима (уп. Burger, 2003; Fleischer, 1997; Kolenić, 1999; Palm, 1997) сасвим извесно да све фразеолошке јединице представљају минималан скуп од две компоненте. Бургер, Бухофер и Сиалм (Burger et. al., 1982) под фразеологизмом подразумевају чврст спој речи у којем лексеме губе првобитно, појединачно значење. Устаљени израз добија ново, јединствено значење и у језику се посматра као лексемска јединица, са чиме се слаже Кристине Палм (Palm, 1997) и на то додаје да спој компоненти унутар једног фразеологизма може да буде регуларан и ирегуларан. Доброволски и Пираинен (Dobrovol'skij \& Piirainen, 2009) фразеологизам дефинишу као хипероним за све чврсте спојеве речи. 
Ослањајући се на Бургера (2003) у овом раду под термином фразеологизам подразумевамо устаљену конструкцију са минималном структуром од две компоненте, без обзира на то којој врсти речи оне припадају, не занемарујући притом морфосинтаксичке промене појединих компоненти.

\section{Основна обележја фразеологизама}

Разликујемо фразеологизме ${ }^{2}$ у ужем и ширем смислу речи. У овом раду се ослањамо на Харалда Бургера (2003), те под фразеологизмима у ужем смислу подразумевамо фразеолошке јединице које карактеришу вишечланост, стабилност и идиоматичност (уп. Burger, 2003; Fleischer, 1997; Palm, 1997). Уколико фразеологизам није идиоматизован спада у групу фразеологизама у ширем смислу речи, што значи да је обележје идиоматичности главни критеријум за ову поделу, а представља семантичку трансформацију компоненти унутар фразеолошке јединице. Према степену идиоматичности разликујемо потпуно идиоматизоване фразеологизме, затим делимично идиоматизоване фразеологизме и фразеологизме који нису идиоматизовани (уп. Burger, 2003; Fleischer, 1997; Palm, 1997). Устаљеност ${ }^{3}$ подразумева да се компоненте фразеологизма не могу заменити другим синонимним изразом, као што је то случај код слободних група речи ${ }^{4}$. Фразеолошке јединице се лексикализују и репродукују као чврст спој речи и као једна целина (уп. Burger, 2003; Fleischer, 1997; Palm, 1997). Полилексичност или вишечланост подразумева минималну структуру фразеологизма као споја две компоненте које могу да припадају како различитом тако и истом скупу речи унутар једне фразеолошке јединице (Burger, 2003). У раду се, због њихове специфичности, ограничавамо на фразеологизме у ужем смислу.

\section{Фразеологизми као компонента комуникативне компетенције}

До седамдесетих година XX века акценат је био на језику као систему правила, било је важно усвојити правила и савладати основне синтаксичке структуpe, док је усвајање лексике и семантике било у другом плану (уп. Nunan, 1999). Циљеви савремене наставе страног језика су, према Заједничком европском референтном оквиру за језике, усмерени на комуникацију односно развијање општих ${ }^{5}$, а пре свега комуникативних компетенција. Под комуникативном компетенцијом подразумевамо језичку рецепцију, продукцију, интеракцију и језич-

\footnotetext{
2 У раду за термин фразеологизам користимо синонимне изразе као што су: фразеолошка јединица, фразеолошки израз, устаљени израз и чврст спој речи (уп. Mršević-Radović, 1987)

${ }^{3}$ Бургер (уп. 2003) разликује психолингвистичку, структуралну и прагматичну стабилност, тј. устаљеност.

${ }^{4}$ Поједини фразеологизми имају и своје варијантне форме (уп. Burger, 2003; Palm, 1997).

${ }^{5}$ Опште компетенције подразумевају декларативна знања (познавање културе земље чији језик се учи, познавање феномена из свакодневног живота, упућеност у географске, демографске, политичке одлике) и процедурална знања (примена декларативног знања односно способност успостављања контакта са припадницима других култура), компетенције које се тичу личности ученика као и способности за учење $(\mathrm{GeR}, 2001)$.
} 
ко посредовање. Уколико говоримо на уопштеном нивоу можемо да кажемо да се комуникативна компетенција састоји из лингвистичке, социо-лингвистичке и прагматичке компетенције (GeR, 2001). За наш рад од посебног значаја је лингвистичка компетенција, будући да се под поменутим појмом подразумева познавање вокабулара и идиоматских израза одређеног језика као и њихових међусобних односа. У поменуту компетенцију се, такође, убраја познавање формалне стране језика (граматике).

С обзиром на то да познавање вокабулара неког језика представља предуслов за успешну комуникацију међу говорницима тог језика, сложићемо ce са Фројденштајновом (Freudenstein, 1992) тврдњом да се комуникација може одржати иако говорник прави граматичке грешке, али, уколико говорник, пак, не влада одређеним вокабуларом, прети опасност да се комуникација прекине. Према Клаусу Ерхарду (2014) за успешну, свакодневну комуникацију поред одређеног броја речи неопходно је и познавање фразеолошких јединица неког језика, како бисмо могли да изразимо али и разумемо одређене мисли, ставове и емоције. Не сме се, пак, запоставити ни граматичка коректност при учењу језика jep судећи по Куку (Cook, 2003), лако може доћи до фосилизације ${ }^{6}$, те се тиме спречава достигнуће вишег језичког нивоа.

У свакодневном животу, било усмено или кроз писани облик, неминовно је да се сусрећемо са великим бројем фразеолошких јединица које, ако се преведу дословно, немају смисла. На тај начин способност разумевања, а самим тим комуникација, бива пољуљана. Познавање језика, по свему судећи, треба да подразумева између осталог и овладавање фразеологизмима тог језика. Фразеолошка компетенција је, како то наводи Клаус Ерхард (2014), саставни део комуникативне компетенције.

Увидом у новију литературу можемо закључити да фразеологизми заслужују све већу пажњу када је комуникативна компетенција у питању (уп. Ehrhardt, 2014; Wray, 2007). Није на одмет истаћи битну улогу фразеологизама када су рецепција информација и продукција говорних исказа у питању. Неки аутори (Ehrhardt, 2014; Fleischer, 1997) сматрају да је основна комуникација без познавања минималног фразеолошког корпуса онемогућена и да би фразеологизми стога требало да представљају важан део наставе страног језика.

\section{Фразеологизми у настави страног језика}

Можемо рећи да, према теорији учења језика, овладавање чврстим спојевима речи доприноси ефикаснијем и бржем савладавању страног језика. С обзиром на то да су фразеологизми изузетно фреквентни када је комуникација међу говорницима у питању, није несхватљиво да се све више аутора залаже за интен-

\footnotetext{
${ }^{6}$ Фосилизација означава појам који се доводи у везу са завршном фазом усвајања страног језика. Реч је о тренутку у коме престаје да се развија ментална представа о језику. На теоријском плану могућа је фосилизација нпр. фонолошког система, док се синтаксичке и семантичке компоненте не могу и даље развијати (уп. Van Patten и Benati, 2010).
} 
зивнију имплементацију фразеологизама у настави страног језика (уп. Bickes и Pauli, 2009; Ehrhardt, 2014). Одређени број аутора (уп. Hallensteinsdóttir, 2001; Hessky, 1997; Jesenšek, 2006) сматра да је важно да се фразеологизми у наставу интегришу од самог почетка учења страног језика јер су фразеолошке јединице неизоставан део језика, без обзира о ком језику се радило. Аргумент који говори у прилог томе је и фактор мотивације. Ерхард (2014) сматра да ученици када једном схвате принцип откривања, разумевања и употребе фразеологизама, желе да знају све већи број фразеологизама како би их и самостално употребљавали. Свакако не смемо заборавити чињеницу да фразеолошке јединице није лако научити у оквиру наставе страног језика и употребљавати у адекватним ситуацијама. Оне због своје специфичности, мисли се на њихове синтаксичке, сематичке и прагматичне особине (уп. Lüger, 1997), захтевају одређени дидактички приступ када је учење у питању. Термин настава страног језика се у овом раду односи на наставу која се одвија у основним или средњим школама и у школама страних језика.

\section{Анализа процене важности употребе фразеологизама у настави страног језика}

Велики број аутора се слаже са тим да су фразеологизми у другом плану када је учење страног језика у питању. Стога сматрамо да је значајно у вези са тим проценити став наставника страног језика који раде у школи.

Из тог разлога осмишљен је анкетни лист на основу којег смо анализирали став наставника у вези са важношћу имплементације фразеолошких јединица у наставу страног језика. Како бисмо у примарном делу нашег рада приказали резултате процене важности о употреби фразеологизама у настави, у раду је коришћена дескриптивна статистичка анализа.

\section{Предмет, методе, технике и инструменти истраживања}

Предмет нашег испитивања је процена важности интеграције фразеологизама у настави из угла наставника страног језика који раде у основним и средњим школама у Србији. За поменуту анализу употребљена је дескриптивна статистика као вид квантитативне анализе података након које следи дескрипција резултата. У анализи резултата се користе нумеричке вредности. Урађена је једноставна дескриптивна анализа, при чему се приказује проценат испитаника који је дао одређени одговор на постављена питања затвореног типа. Након логичке контроле и уноса прикупљених података извршено је табелирање и статистичка обрада резултата. Техника којом смо се служили приликом испитивања су: анкетирање и проценивање, при чему инструменте анализе чини анкетни лист са петостепеном Ликертовом скалом. Анкетни лист садржи уводне напомене и информације помоћу којих се врши анализа структуре узорка истраживања. У питању су следећи параметри: пол, страни језик на нивоу постигнућа од А1 до Б1, место, тип школе (основна, средња или школа страних језика), први или други страни језик 
и радни стаж наставника. Анализирана је процена наставника страних језика на основу питања о томе да ли су фразеологизми важан део наставе страног језика, да ли је употреба фразеологизама значајна од самих почетака учења језика, да ли су фразеолошке јединице неизоставан део када желимо да комуницирамо са матерњим говорницима неког језика и да ли је неопходно посветити више пажње устаљеним изразима.

\section{Хипотезе, циљеви и задаци истраживања}

У истраживању смо пошли од претпоставке да већина наставника неће сматрати да су фразеологизми важан део наставе страног језика, као и да не придају значај када је у питању учење фразеолошких јединица од самих почетака учења страног језика. Наша претпоставка је поткрепљена чињеницом да велики број савремених аутора сматра да су фразеологизми неправедно запостављењи у настави страног језика, те се апелује на квалитетнију и чешћу интеграцију истих (уп. Bickes и Pauli, 2009; Ehrhardt, 2014; Wray, 2007). Претпоставили смо, међутим, да је велики број наставника свестан чињенице да је познавање фразеологизама битно уколико се жели несметано комуницирати са матерњим говорницима језика који се учи. Верујемо да се наставници, упркос наведеном, не залажу за интензивнију имплементацију фразеолошких јединица у настави страног језика. До ове претпоставке смо дошли на основу сарадње, те и непосредног разговора са великим бројем предавача страног језика.

Циљ нашег истраживања је извођење општих закључака у вези са ставовима наставника на одређене тврдње и утврђивање тачности наших претпоставки док се фокусирамо на питање да ли су и у којој мери наставници страног језика свесни важности имплементације фразеолошких јединица у наставу страног језика.

\section{Узорак истраживања и организација истраживања}

Инструменте испитивања применили смо на узорку наставника страних језика. Случајан узорак за све школе састојао се од 54 испитаника: од тога 33,33\% наставника из основне школе, $31,48 \%$ наставника из средње школе и 35,19\% наставника из школе страних језика. Број наставника страног језика који је обухваћен анкетирањем приказан је у графикону 1. 
Графикон 1. Број испитаника распоређених према основним, средюим школама и школама страних језика:

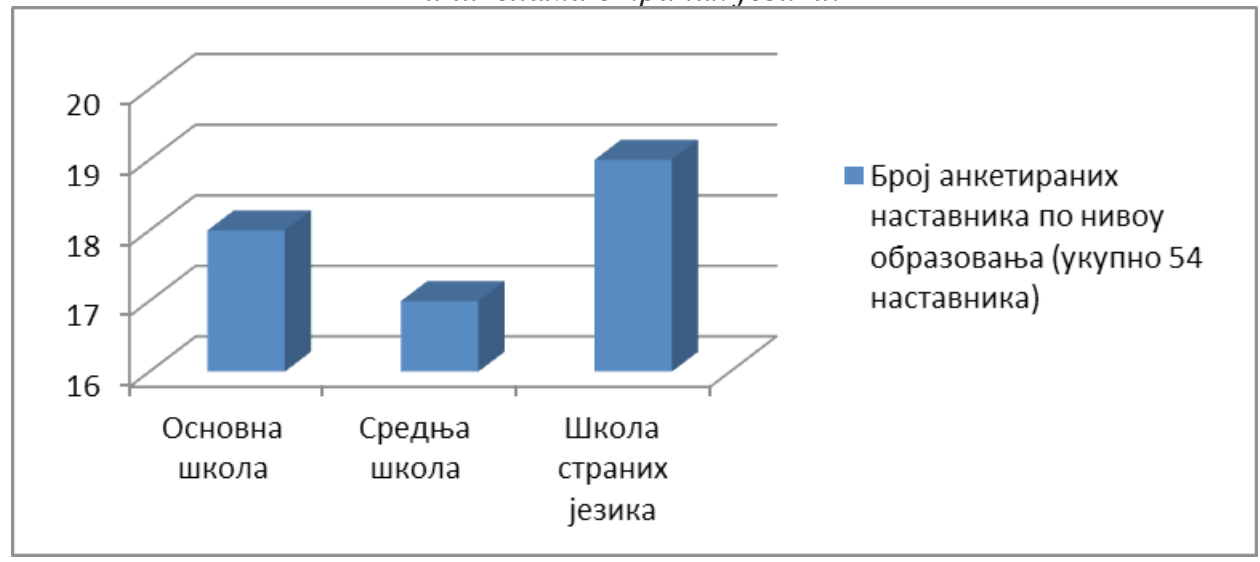

Сви наставници страног језика поседују од једне до тридесет и седам година радног искуства у струци. Испитивање је вршено у основним и средњим школама, као и у школама страних језика. Од 54 испитаника седам је мушког а 47 женског пола.

Табела 1. Број испитаника распоређених према полу:

\begin{tabular}{|c|c|}
\hline Пол наставника: & Бр. наставника (\%): \\
\hline Женски пол & $87,04 \%$ \\
\hline Мушки пол & $12,96 \%$ \\
\hline
\end{tabular}

Као први страни језик предаје 40, док преосталих 14 наставника страни језик предаје као други страни језик у основним и средњим школама.

Табела 2. Број испитаника распоређених према језику који предају као први или други страни језик:

\begin{tabular}{|l|c|}
\hline \multicolumn{1}{|c|}{ Први/други страни језик: } & Бр. наставника (\%): \\
\hline Први страни језик & $74 \%$ \\
\hline Други страни језик & $26 \%$ \\
\hline
\end{tabular}

Енглески, немачки, руски, италијански, француски и грчки језик су страни језици који су обухваћени испитивањем. Анкетирање наставника је спроведено у десет места у Србији који су приказани у графикону 2. 
Графикон 2. Број испитаника распоређених према месту у којем предају страни језик:

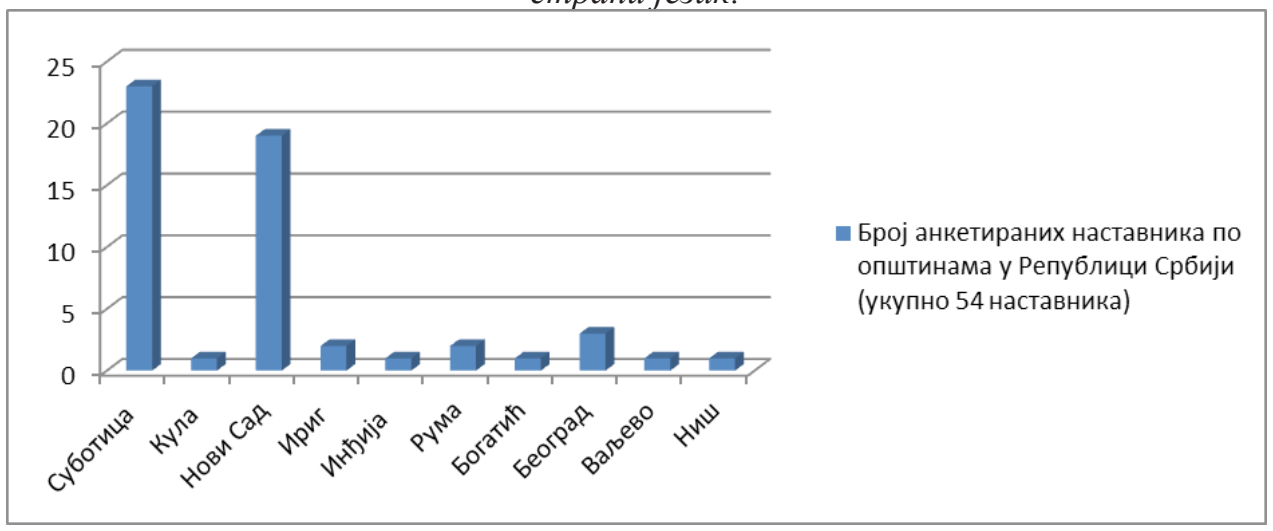

У истраживању смо применили трансверзални приступ (уп. Dörnyei, 2007) - у одређеном временском периоду смо на више места, у различитим условима извршили анкетирање наставника различитих страних језика. Анкетирање је било анонимно, а вршено је у току првог полугодишта школске 2016/2017. године.

\section{Резултати анализе анкетних листова за наставнике страног језика}

Резултате ставова наставника ћемо представити посебно према свакој тврдњи. Тумачићемо обједињено одговоре наставника који раде у основним, средњим школама и школама страних језика, са циљем да лакше уочимо опште закључке када су у питању ставови наставника страног језика према фразеологизмима.

На питање о томе да ли су фразеологизми важан део наставе велики број наставника се сложио са тим да фразеологизми јесу битни када је учење страног језика у питању. Двадесет и пет наставника, или 46,30\%, од укупно педесет и четири наставника се у потпуности сложило са исказом, док је 48,15\% наставника одговорило да се углавном слаже са поменутим ставом. Дакле, може се рећи да већина наставника $(94,45 \%)$ сматра фразеолошке јединице важним делом наставе када је страни језик у питању. Два наставника су била неодлучна (3,70\%), а само се један наставник углавном не слаже са исказом $(1,85 \%)$. Нико од испитаника није био става да су фразеологизми неважни у оквиру наставе страног језика.

На питање да ли је важно да се фразеологизми усвајају од самих почетака учења страног језика, једанаест испитаника (20,37\%) се у потпуности слаже са ставом да је битно усвајати фразеологизме од самих почетака учења страног језика, а 40,74\% наставника се углавном слаже са исказом. Закључујемо да је више од половине испитаника $(61,11 \%)$ позитивног става када је у питању усвајање фразеолошких јединица од самих почетака усвајања језика. Десет испитаника 
$(18,52 \%)$ је било неодлучно, док се девет $(16,67 \%)$ углавном не слаже са ставом осталих. Два испитаника се уопште не слажу са исказом.

Више од половине испитаника $(53,70 \%)$ се у потпуности слаже са ставом да је неопходно познавати фразеолошке јединице уколико се жели несметано комуницирати са матерњим говорницима одређеног језика. Двадесет наставника $(37,03 \%)$ се углавном слаже са поменутом тврдњом, док је петоро неодлучно $(9,27 \%)$. Ниједан испитаник није дао негативан одговор да се делимично или у потпуности не слаже са исказом. Дакле, 90,73\% испитаника, од укупног броја, свесно је значаја фразеологизама за комуникативну компетенцију.

Са последњим исказом да се више пажње треба посветити фразеологизмима у настави страног језика у потпуности се слаже $35,20 \%$ наставника (од укупног броја испитаника). Двадесет и један наставник (38,90\%) се углавном слаже, али је $12,96 \%$ испитаника неодлучно поводом поменутог исказа. Пет наставника $(9,24 \%)$ се углавном не слаже да је неопходно посветити више пажње употреби фразеологизама у настави страног језика. Два наставника се уопште не слажу са тим да треба више пажње обратити на поменуте спојеве речи.

\section{Закључак о анализи анкетних листова за наставнике страног језика}

Закључак о анализи анкетних листова ћемо тумачити посебно према сегментима истраживања обрађеним у раду. Анкетирање испитаника извршено је на основу четири сегмента.

Први сегмент анализе односи се на значај употребе фразеологизама у настави страног језика. Други сегмент анализе подразумева тумачење резултата у вези са усвајањем фразеолошких јединица страног језика, од самих почетака учења језика. Трећи сегмент усмерили смо на анализу резултата о ставу да су фразеологизми неизоставан део успешне комуникације са матерњим говорницима одређеног језика који се учи. У оквиру четвртог сегмента анализе тумачили смо резултате везане за интензивнију имплементацију фразеологизама у наставу током учења страног језика. Анализирајући ставове наставника на први исказ закључили смо да су наставници, судећи према анкетном листу, изузетно свесни важности фразеологизама, када је настава страног језика у питању. Чак 94, 45\% испитаника сматра фразеологизме важним делом наставе страног језика. Добијени резултати анкетирања за овај сегмент су изненађујући, а с обзиром на претпоставку од које смо пошли у раду. Судећи према новијој литератури, веровали смо да наставници фразеологизме неће сматрати значајним - интересантно је да се нико од испитаника није у потпуности сложио са нашом претпоставком. На основу резултата, у вези са другим исказом, закључујемо да је поново више од половине наставника свесно важности имплементације фразеологизама у наставу, од самих почетака учења страног језика, што је супротно нашим очекивањима. С једне стране јесте занимљиво да се више од половине испитаника сложило са исказом, али је с друге стране интересантно да више од једне трећине испитаника $(38,89 \%)$ не дели мишљење са великим бројем аутора који апелује на усвајање фразеологизама од 
самих почетака учења страног језика. То је свакако показатељ да наставници нису свесни у којој мери је важно да се фразеологизми усвајају од најнижег нивоа учења језика. У складу са нашим очекивањима наставници су у великој већини истакли да су фразеологизми неизоставан део када је несметана комуникација са матерњим говорницима одређеног језика у питању. Поред тога, ниједан наставник није мишљења да је трећи исказ нетачан или делимично нетачан. Ови резултати нису изненађујући с обзиром на то да смо од почетка претпоставили да су наставници свесни у којој мери матерњи говорници у свакодневном говору користе фразеологизме и колико су заступљени када је несметана комуникација у питању. Такође, наша претпоставка је да наставници не деле мишљење о томе да треба обратити више пажње на фразеологизме у настави страног језика и увидети да су неправедно запостављени у односу на друге области језика које се уче. Анализирајући одговоре наставника на четврти исказ увиђамо да су, позитивно изненађујуће у односу на нашу хипотезу, наставници у већини (74,10\%) спремни да посвете више пажње чврстим спојевима речи за време наставе страног језика. Са друге стране, примећујемо да чак скоро једна трећина испитаника не сматра важним да се обрати већа пажња на имплементацију фразеологизама у наставу. Анализирајући ставове наставника према исказима (о којима је било речи) закључујемо да су наставници у великом броју, а судећи према попуњеним анкетним листовима, свесни важности имплементације фразеологизама у наставу страног језика, али да постоји одређени број испитаника, који не дели мишљење са остатком испитаника, те је става да су фразеолошке јединице маргиналне.

\section{Закључна разматрања}

У раду смо разматрали у којој мери су наставници страног језика свесни важности имплементације фразеологизама у наставу страног језика, а у циљу достизања квалитетне језичке компетенције ученика. На основу добијених и представљених резултата јасно је да су наставници, судећи по одговорима из анкетног листа, свесни важности фразеолошких јединица када је комуникативна компетенција и учење фразеологизама у питању. Општи закључак је да је већина наставника свесна значаја употребе фразеолошких јединица од самих почетака подучавања страног језика, као и да је спремна посветити више пажње овим чврстим спојевима речи - што је супротно мишљењу већине аутора.

Стога сматрамо да би било пожељно анализирати дидактичко-методички приступ наставника када је обрада и усвајање фразеолошких јединица од стране ученика у питању, како би се установило да ли се добијени ставови примењују и у самој наставној пракси. Осим тога, верујемо да би било значајно испитати фразеолошку компетентност ученика који уче страни језик. Испитивање би могло да се ограничи на усвојене фразеологизме који се појављују у уџбеницима и радним свескама који/које се користе у оквиру наставе (као и на основу потенцијалног додатног материјала уколико га наставник користи). За нека даља истраживања интересантно би било анализирати корелацију добијених одговора 
између основног односно средњег образовања, година стажа наставника и страног језика који се предаје. Поред постизања комуникативне компетенције код ученика, познавање и примењивање фразеологизама неког страног језика могу да допринесу томе да се народ и култура језика који учимо боље упознају. На тај начин се код ученика развија отвореност према свему што је страно и подстиче се размишљање о култури других народа и народности, што је свакако значајан васпитни циљ наставе. Сматрамо да би овај рад могао бити полазиште за даљу анализу у оквиру теме у ужем и ширем смислу.

\section{Литература}

Bickes, H. \& Pauli, U. (2009). Erst- und Zweitsprachenerwerb, Paderborn: Fink.

Burger, H., Buhofer, A., \& Sialm, A. (1982). Handbuch der Phraseologie, Berlin; New York: Walter de Gruyter.

Burger, H. (2003). Phraselogie. Eine Einführung am Beispiel des Deutschen, Berlin: Erich Schmidt Verlag.

Cook, G. (2003). Applied Linguistics, Oxford: Oxford University Press.

Dobrovol'skij, D., \& Piirainen, E. (2009). Zur Theorie der Phraseologie, kognitive und kulturelle Aspekte, Mannheim: Stauffenburg Verlag.

Dörnyei, Z. (2007). Research Methods in Applied Linguistics. Quantitative, Qualitative, and Mixed Methodologies, Oxford: Oxford University Press.

Ehrhardt, C. (2014). Idiomatische Kompetenz: Phraseme und Phraseologie im DaFUnterricht, dostupno na: http: //www. gfl-journal. de/1-2014/Ehrhardt. pdf (pristupljeno 20. februara 2017. ).

Fleischer, W. (1997). Phraseologie der deutschen Gegenwartssprache, Tübingen: Max Niemeyer Verlag.

Freudenstein, R. (1992). Wählen Sie Kanal 93! Unterrichtsmaterialien für das 21. Jahrhundert, Informationen Deutsch als Fremdsprache 19, 543-550.

GeR (Der Gemeinsame europäische Referenzrahmen für Sprachen: lernen, lehren, beurteilen), (2001), dostupno na: http: //www. europaeischer-referenzrahmen. de/, (pristupljeno 3. marta 2017. ).

Hallensteinsdóttir, E. (2001). Das Verstehen idiomatischer Phraseologismen in der Fremdsprache Deutsch, dostupno na: http: //www. verlagdrkovac. de/ volltexte/978-3-8300-0435-6. htm, (pristupljeno 14. marta 2017.).

Hessky, R (1997). Einige Fragen der Vermittlung von Phraseologie im Unterricht Deutsch als Fremdsprache, Wortbildung und Phraseologie, 255-261.

Jesenšek, V. (2006). Phraseologie und Fremdsprachenlernen. Zur Problematik einer angemessenen phraseodidaktischen Umsetzung, dostupno na: https: //bop. unibe. ch/linguistik-online/article/view/747, (pristupljeno 20. marta 2017. ).

Kolenić, Lj. (1999). Kako prepoznati frazem, Teorija i mogućnost primjene pragmalingvistike, 377-382.

Lüger, H-H. (1997). Anregungen zur Phraseodidaktik, Beiträge zur Fremdsprachevermittlung 32, 69-120. 
Mršević Radović, D. (1987). Frazeološke glagolsko-imeničke sintagme u savremenom srpskohrvatskom jeziku, Beograd: Filološki fakultet, Naučna knjiga.

Nunan, D. (1999). Second Language Teaching \& Learning, Boston; Massachusetts: Heinle \& Heinle Publishers.

Palm, C. (1997). Phraseologie. Eine Einführung, Tübingen: Gunter Narr Verlag.

VanPatten, B., \& Benati, A. (2010). Key Terms in Second Language Acquisition, London; New York: Continuum.

Wray, A. (2007). Set phrases in second language acquisition, Phraseologie, Phraseology $2,870-881$.

\title{
MA Nataša R. Kurtuma
}

Phd Gordana M. Ristić

Faculty of Philosophy, University of Novi Sad

\section{ABOUT THE IMPORTANCE OF IMPLEMENTING PHRASEOLOGISMS IN FOREIGN LANGUAGE CURRICULUM}

\begin{abstract}
The aims of a contemporary curriculum of a foreign language, according to the Common European Framework of Reference for Languages, are directed towards communication, i. e. the development of general competences, above all, communicative competence. The necessity to be able to communicate with speakers of a foreign language without greater difficulties and that the command of language does not extend to certain linguistic areas alone is more and more common. For a successful everyday conversation, among other things, it is important to be familiar with phraseological units of a language. The question that arises in this thesis is - to what extent foreign language teachers are aware of the importance of implementing phraseologisms in a foreign language curriculum. The technique used in the research was surveying and the instrument of analysis was a five-point Likert scale questionnaire. Descriptive statistics, as a method of quantitative data analysis, was used for the survey after which description of the result followed. The aim of the research, using descriptive statistics as a method, is making general conclusions about teachers' attitudes towards certain statements as well as determination of the accuracy of our assumptions, with focus on the implementation of phraseologisms in a foreign language curriculum. It would be interesting for further research to analyze the correlation between the answers received in elementary i. e. secondary education, length of employment of teachers and foreign language he or she teaches. We believe that this thesis could be a starting point for further analysis of this topic.
\end{abstract}

Key Words: communicative competency, phraseologic competency, phraseologisms, foreign language curriculum, teachers' attitudes 